\title{
Research on Passive Design Optimization about an Experimental Rural Residence in Hot Summer and Cold Winter Region of China
}

\author{
Qian $\mathrm{Wu}^{1,2^{*}}$, Weijun Gao ${ }^{2}$ \\ ${ }^{1}$ School of Civil Engineering and Architecture, Zhejiang University of Science and Technology, Hangzhou, China \\ ${ }^{2}$ Faculty of Environmental Engineering, The University of Kitakyushu, Kitakyushu, Japan \\ Email: wuqian1003@163.com
}

How to cite this paper: $\mathrm{Wu}, \mathrm{Q}$. and Gao, W.J. (2016) Research on Passive Design Optimization about an Experimental Rural Residence in Hot Summer and Cold Winter Region of China. Journal of Building Construction and Planning Research, 4, 131-156. http://dx.doi.org/10.4236/jbcpr.2016.43009

Received: April 15, 2016

Accepted: August 7, 2016

Published: August 12, 2016

Copyright $\odot 2016$ by authors and Scientific Research Publishing Inc. This work is licensed under the Creative Commons Attribution International License (CC BY 4.0).

http://creativecommons.org/licenses/by/4.0/ c) (i) Open Access

\begin{abstract}
In China, rural residential environment under the poor construction measures has not been satisfactory due to the backward infrastructure of countryside and the lacking of professional planning, which will result in considerable amount of energy consumption in the future. The economy of rural residences in the hot summer and cold winter region of China is relative developed, but the indoor thermal environmental quality is not so good. In this paper, the design strategies directed by passive design ideas for a small experimental rural residential building located in Hangzhou city was introduced and researched in response to hot summer and cold winter climate. Through modeling solution undertaken by Ecotect software, the building performance was simulated and analyzed for the optimization of design factors, such as shape, roof angle, insulation system, shading devices, as well as day-lighting system. Based on the above study, a set of appropriate energy-saving technologies were provided for improving the new rural residences construction in Hangzhou, which should also be recommended to other projects constructed in the same climate region.
\end{abstract}

\section{Keywords}

Hot Summer and Cold Winter Region, Rural Residence, Passive Design, Simulation

\section{Introduction}

Since October of 2005, one important historical task was determined by Chinese government to develop the socialist new countryside consisting of constructing advanced rural residences and improving people's living conditions. Based on the report [1], the area of rural residences in 2010 reached 23 billion $\mathrm{m}^{2}$, about $50 \%$ of national total area 
in this year; by 2020 , it is estimated that the rural building area will reach 42.5 billion $\mathrm{m}^{2}$, responsible for $62 \%$ [2] of the total gross floor area in China. Due to the backward infrastructure of countryside and the lacking of professional planning, rural residential environment under the poor construction measures has not been satisfactory for ignoring the environmental factors, such as climate, building directions, natural ventilation and so on, which will lead to considerable amount of energy consumption in the future [3].

China's territory ranges from $18^{\circ} \mathrm{N}$ to $53^{\circ} \mathrm{N}$ and covers five different climatic regions (see Figure 1) across the mainland: severe cold region, cold region, moderate region, hot summer/cold winter region, and hot summer/warm winter region, among of which the hot summer/cold winter region contains $40 \%$ of population, $20 \%$ of national territorial area, and $48 \%$ of the gross national product. The climate condition in hot summer/cold winter region is relevant severe: the monthly mean temperature ranges from $15^{\circ} \mathrm{C}$ to $30^{\circ} \mathrm{C}$ and peaks at $40^{\circ} \mathrm{C}$ in July. During the summer months of May through September, the relative humidity is remarkably high, from $70 \%$ to $80 \%$. While the winter months of November to February show an average temperature of $4^{\circ} \mathrm{C}$ and the minimum of $-10^{\circ} \mathrm{C}$ in January.

Hangzhou belongs to the hot summer/cold winter region, characterized by $118.35^{\circ} \sim$ $120.5^{\circ}$ East longitude and $29.18^{\circ} \sim 30.55^{\circ}$ North latitude. As the capital of Zhejiang province, Hangzhou city has a relatively developed economy in rural area. According to 2008 figures reported by the Hangzhou city bureau of statistics (NBS), the rural per capita net income had broken through 10,000 RMB [4] (see Figure 2). Since reform and opening up in the eighties of China, the number of new rural residences has increased sharply. In 2010, researchers carried out the investigation on the construction, materials, indoor thermal environment of rural residences in the 11 districts including 20 villages of

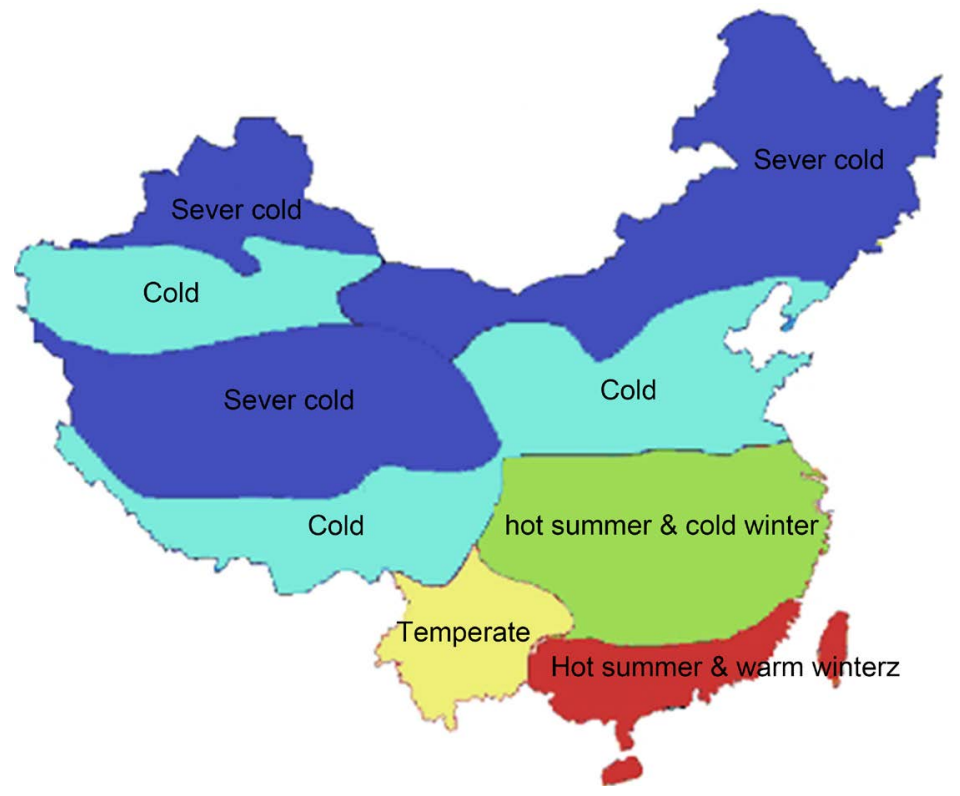

Figure 1. The map of five climate regions of China. 
Zhejiang [5]. The results of research indicated that from 1980-2000, the amount of rural residential buildings accounted for $32 \%$ of the total construction. Due to the reason that heat insulation and natural ventilation for buildings had not been considered, the $50 \%$ of villagers used to buy air conditioners to improve the comfort level of indoor thermal environment which led to the increasing of energy consumption [5]. Reference [6] introduced a field survey carried out in three typical villages including 150 households around Hangzhou to investigate the human environment and energy consumption. In this survey, several findings were provided: a) the ownership of solar water heaters accounted for $70 \%$ in all the households, but lacking other renewable energy utilization; b) more than $50 \%$ of households had air conditioners, consuming $50 \%$ of residential energy; c) less than $50 \%$ of households showed the satisfactory to the indoor thermal environment and the evaluation to the summer was more poor than the winter; d) large window areas was popular for ventilation and good sight, but conducted the problems of over hot in summer and cold in winter. Thus, the air conditioner has been the necessity in rural residents' life. Figure 3 shows the ownership of air conditioners per 100 households, where can be seen that the number has broken through 100 in 2010 and increased year by year.

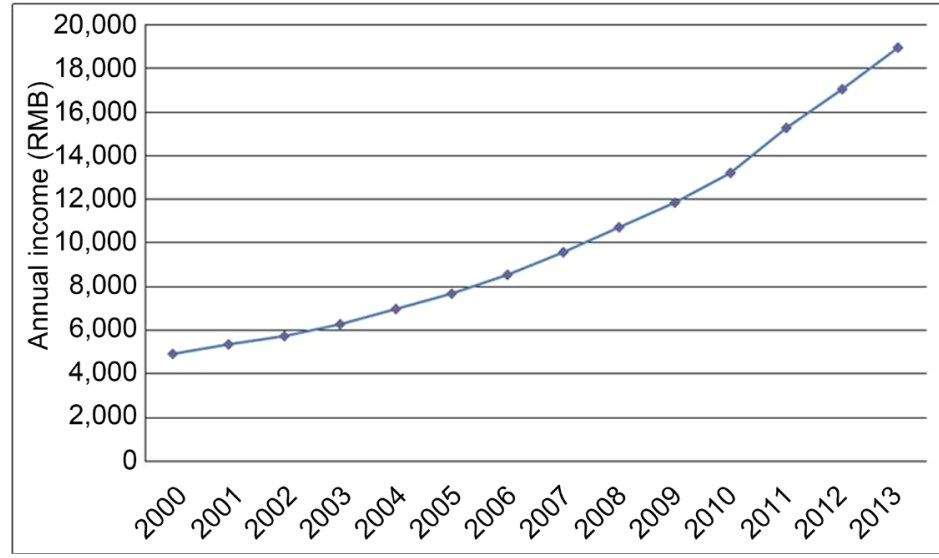

Figure 2. Annual income per rural resident from 2000 2013.

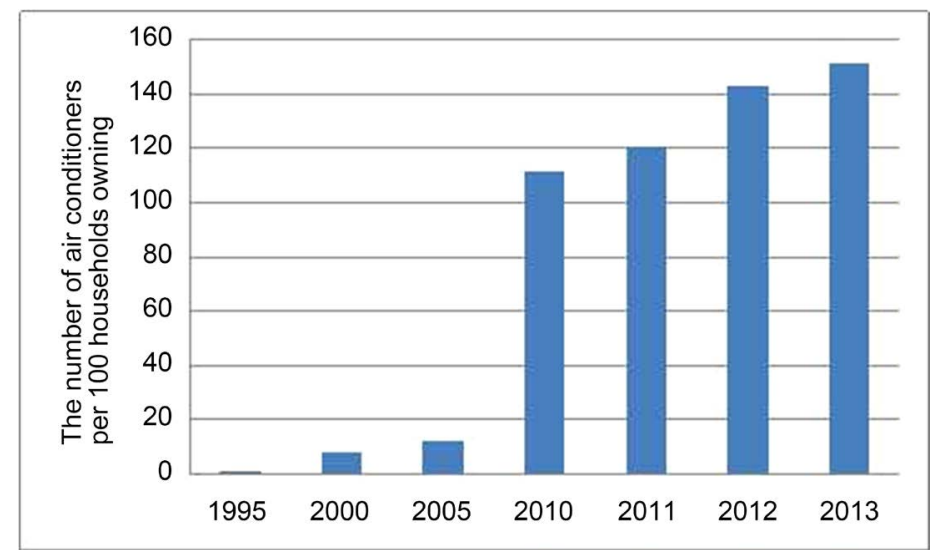

Figure 3. The ownership of air conditioners per 100 households in Hangzhou rural area. 
In this paper, the design strategies of a small experimental residence directed by passive design ideas was introduced and researched in response to Hangzhou climate. Through modeling solution undertaken by Ecotect software, the building performance was simulated and analyzed for the optimum combination of design factors. Based on the above study, a set of appropriate energy-saving technologies were provided for improving the new rural residences construction in Hangzhou, which should also be recommended to other projects constructed in the same climate region.

\section{Critical Review of Previous Studies}

The design idea of passive energy building was firstly suggested by American Architect Bernard Baruch, the purpose of which was to achieve highest thermal comfort conditions on low total costs through making full use of renewable energy resources to reduce fossil energy consumption, and to achieve highest thermal comfort conditions on low total costs.

Nowadays, passive cooling and heating techniques have been increasingly encouraged by international regulations. According to the reference [7], passive cooling relies on the use of techniques that enable controlling and dissipating the solar radiation and thermal gains during summer. Contrarily, heat passive features take advantage of sunlight and its heating effect thanks to their high capacity of absorbing solar radiation, storing and releasing heat inside the building.

\subsection{Theoretical Exploration}

Reference [8] introduced the difference of energy-saving techniques between China and Europe, and carried out the feasibility on the implementation of passive design in the severe cold region, cold region and hot summer/cold winter region of China. The results indicated that improving the design and construction level of energy-saving buildings in China could be realized through demonstration projects practiced in the above regions due to the huge energy efficiency potential. In this study [9], the climatic parameters should be considered for the designing of energy-saving residential buildings in the hot summer/cold winter region. Several factors such as shape coefficient control and window-wall ratio were concluded as the crucial strategies for energy efficiency. Reference [10] demonstrated the concept, heat gaining and design proposal about the solar energy residences, summarized the methods of solar energy utilization on planning and design.

\subsection{Practice Exploration}

An experimental transformation of two apartment units in Beijing was demonstrated in the reference [11] how a passive ecological design can become a systematic tactics to transform a conventional residence to a green building by using local natural resources through sunlight room, solar thermal collectors, rainwater collection and interior ecological wall. Reference [12] presented a small low-energy green building located in the suburb of Hangzhou which was designed combining with active and passive methods 
such as solar energy technologies, enhanced insulation system of envelope and so on. According to the reference [13], the first passive public building was constructed as a demonstrative project in Changxing county of Zhejiang province by using the "Passive house" standard of Germany for reference, which explored the potential of realizing the low-energy building practice in the hot summer/cold winter region and summarized the construction experience.

\subsection{Computer Simulation}

Computer simulation is a useful method for architects and engineers to simulate and analyze building performance earlier in the design process. The indoor thermal environment of the residences in Turpan District of Xinjiang was simulated and analyzed by using Ecotect software in the reference [14] to evaluate the thermal performance of primary scheme related to the solar radiation, heating consumption and indoor comfort level. Reference [15] carried out a simulation analysis of indoor hourly temperature towards a library building for the insulation material optimization.

Based on the above literature, there are very few studies on passive rural residential buildings design in response to the climate of hot summer/cold winter region. In this study, the "passive" design concept was considered firstly through appropriate plan arrangement, building shape optimization and construction materials selection to largely improve indoor thermal comfort and reduce energy consumption. Secondly, affordable technology equipments were integrated in this project for the purpose of gaining renewable energy actively, supplying energy to building and decrease the need of fossil energy. Furthermore, this project is not a real residential building while is an experimental model integrated with various adaptable energy-saving techniques to be studied and investigated or to be modified and changed into more advanced product in future.

\section{Passive Design Strategies}

Hangzhou is a typical city in the hot-summer and cold-winter zone. According to the statistic [16], the average temperature in July was about $30.6^{\circ} \mathrm{C}$ in 2006 . Especially in July and August, the solar radiation is at the peak, while the maximum temperature occasionally exceeded $40^{\circ} \mathrm{C}$ and the minimum was commonly about $28^{\circ} \mathrm{C}$ in the view of history after the rainy season, which is an important factor causing the extreme clear and hot high temperature event, leading to the poor indoor thermal environment in the summer of Hangzhou. On the other hand, the average temperature in January was about $4^{\circ} \mathrm{C}$ and the relative humidity was about $80 \%$ that resulted in the wet and cold indoor environment in winter.

Based on the above analysis, the design strategies response to the Hangzhou climate should be concluded as following:

1) to largely gain solar radiation energy and highly enhance envelope insulation in winter;

2) to induce nature ventilation efficiently and control the amount of solar radiation admitted into the room by using appropriate shading devices in summer. 
As mentioned above, an experimental residential building was designed with the height of $2.8 \mathrm{~m}$ and the area of $50-60 \mathrm{~m}^{2}$, characterized by a symmetrical layout (see Figure 4): two bedrooms were on the both sides of the living room being oriented south. The other rooms, kitchen and toilet, were at the back of the main rooms facing north. This arrangement is set on a basis that main rooms requiring heating in winter should be at the area with less temperature difference of indoor and outdoor for reducing the heat transferring loss through the building envelope. Several passive design strategies were introduced as following:

1) The final plan was the result of being simulated and compared by Ecotec software analysis, as illustrated in the session 4, seen in Figure 4, Figure 5.

2) Considering application of thermal pressure ventilation in summer, a patio space was set at the back of the middle room with a rectangular air duct of $4.5 \mathrm{~m}$ high above the roof, which connected indoor space with outside environment through a horizontal rectangular inlet opening located on the room ceiling, forming a solar chimney structure. Figure 6 and Figure 7 indicated the side elevation and the structure section sketch respectively. The operation of this passive ventilation system was illustrated in Figure 8.

3) In the early study [17], the solar energy resource of Hangzhou was assessed according to the weather file of Typical Meteorological Year (TMY) of Hangzhou. The result indicated that the solar room should be recommended for the insulation and solar gains in winter towards the construction of rural residences in Hangzhou. The south external wall of the living room was designed with the thermal storage wall combined with glass boxes as the main component for heating the inside room (see Figure 9). Figure10 and Figure 11 represent the operation of such solar collector wall in winter and summer.

4) For the better utilization of roof as solar energy collector, the session 4 introduced that the Ecotect software was applied to simulate the total solar radiation falling on the middle roof with different angle. At the end, the optical angle was $30^{\circ}$ combined with the solar chimney for the aesthetic style, shown in Figure 6.

5) The popular preference of larger window areas in residential buildings is usually for the better viewing and lighting, but also resulting in the huge energy compensations. The natural optical light system was applied in the living room for reducing the influence of solar radiation. The principle of natural optical light system was shown in Figure 12, and the session 4 illustrates the analysis process and predicts the indoor lighting situation adjusting the dimension size of the mental tube and window area.

6) During the building operation, the external construction is an important way for heat transferring resulting in large amount of energy consumption. Therefore, building envelope insulation deserves high attention including wall, roof and window. In this project, local economically materials and common thermal insulation system were considered, the performance of which were both higher than the president regulation Design standard for energy efficiency of residential buildings in hot summer and cold winter zone banned by the Ministry of Housing and Urban-Rural 
Development of China. The material and construction method was shown in Table 1, and the construction details of roof and wall were displayed in Figure 13 and Figure 14.

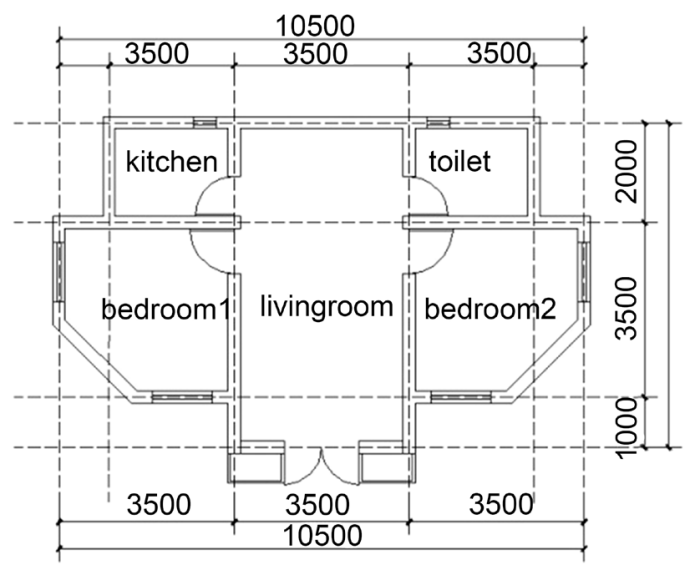

Figure 4. Plane.

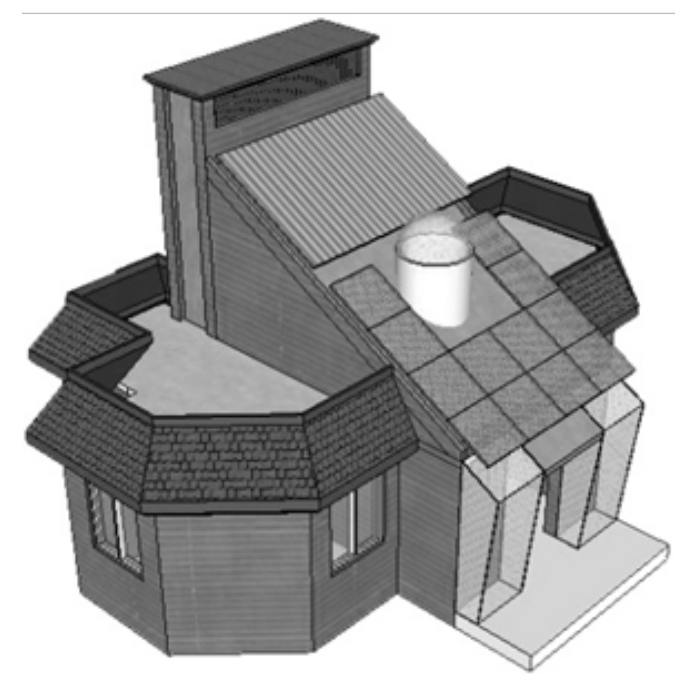

Figure 5. Design sketch.

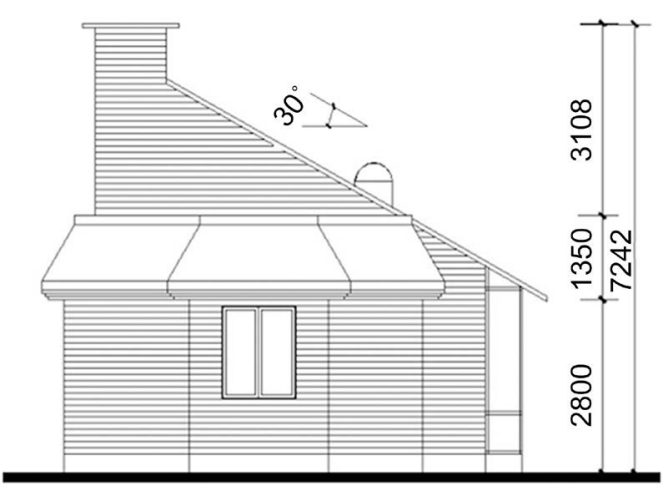

Figure 6. Side elevation. 


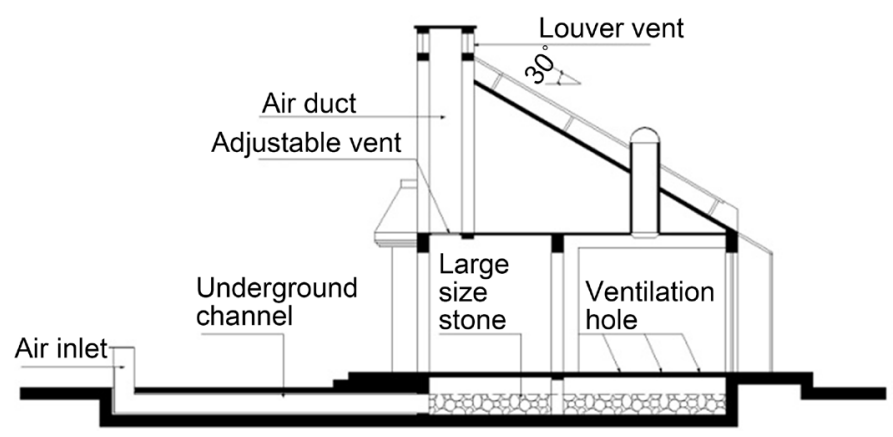

Figure 7. The section sketch of the passive ventilation system.

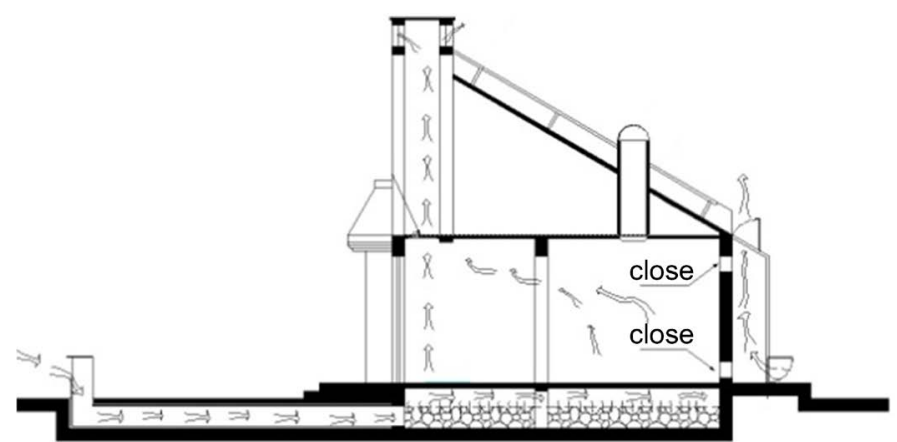

(a)

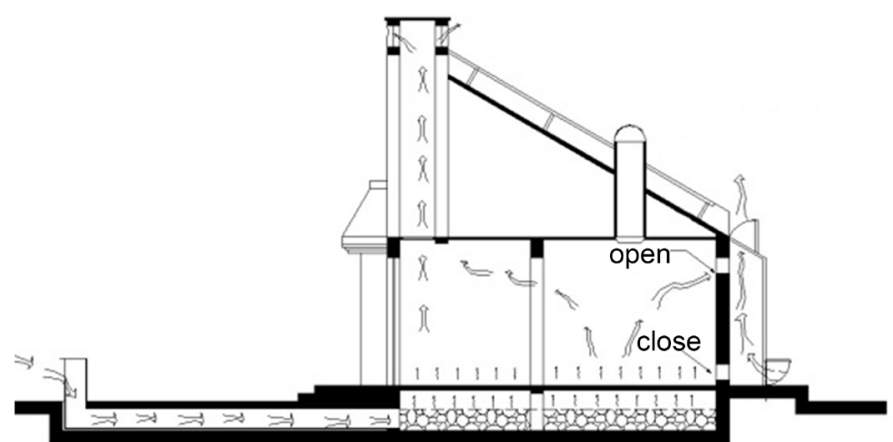

(b)

Figure 8. The operation of passive thermal pressure ventilation in summer (a) Daytime; (b) Nighttime.

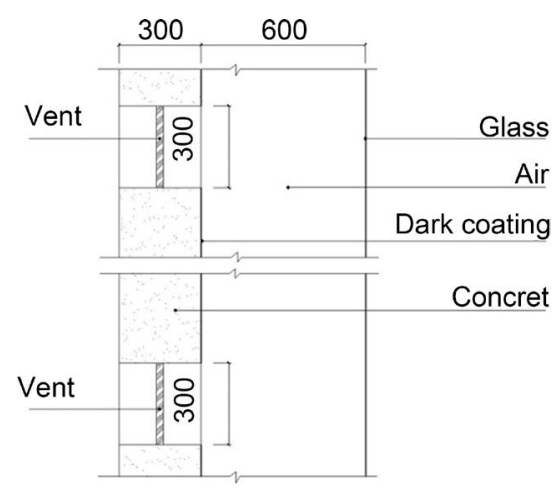

Figure 9. The construction details of solar collector wall. 

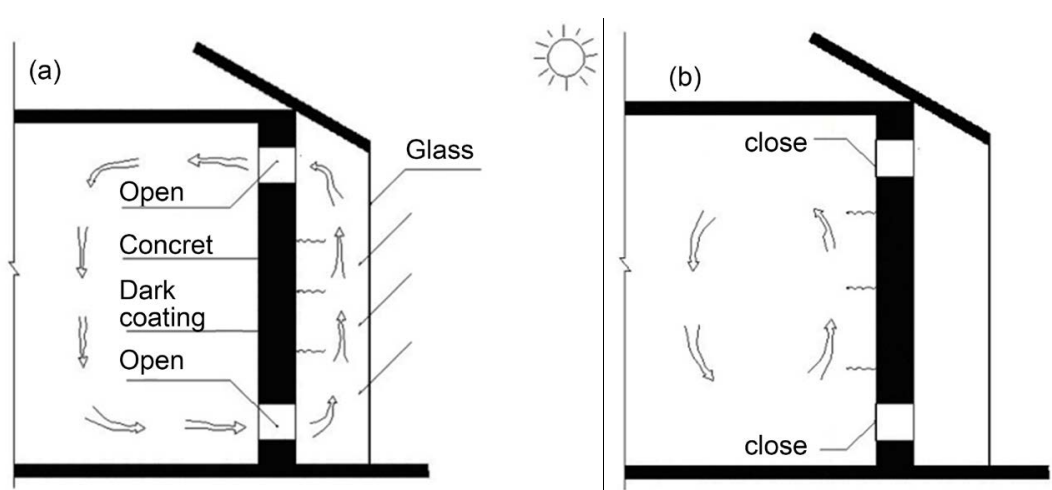

Figure 10. The operation of solar collector wall in winter (a) Daytime; (b) Nighttime.
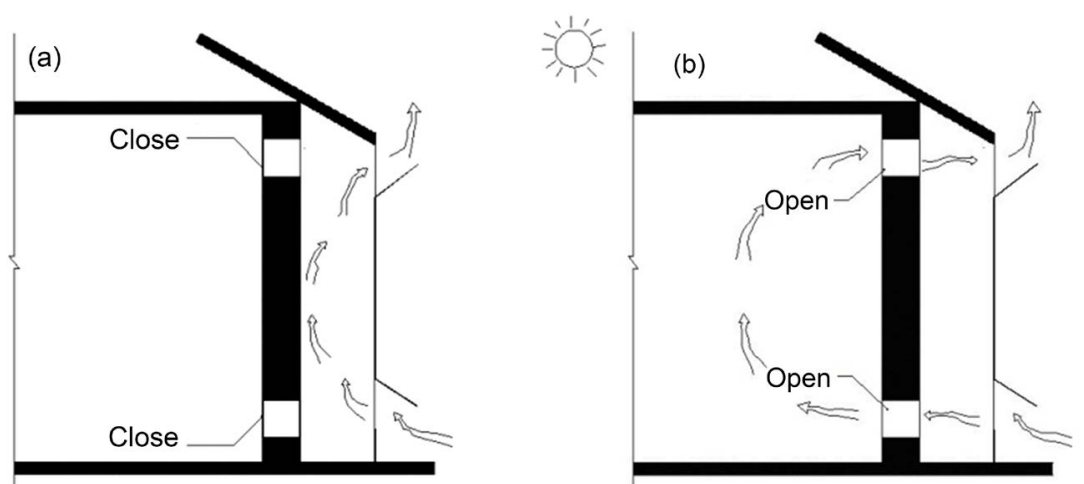

Figure 11. The operation of solar collector wall in summer (a) Daytime; (b) Nighttime.

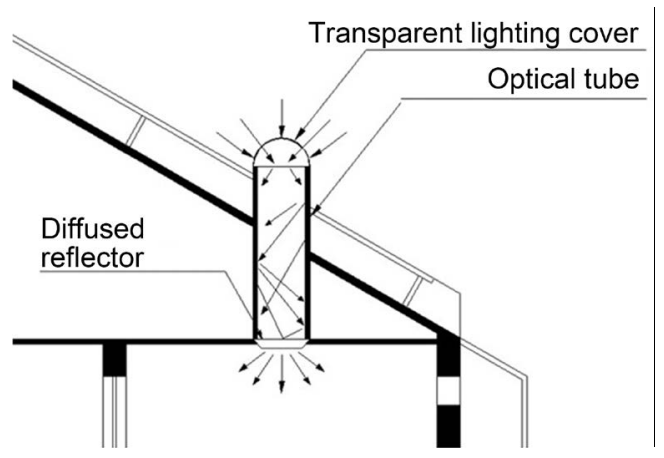

Figure 12. The principle of natural optical light system.

\section{Tool and Methodology}

The Ecotect software is a useful tool to analyze the variable physical environment and predict the energy consumption through simulating the building, for the further research and optimization on the preliminary scheme. This software was developed for architects and engineers to carry out sustainable analysis on variable physical environment during the conceptual design, including: thermal environment (heating/cooling load, energy consumption simulation, hourly temperature analysis and so on); wind environment (nature ventilation, solar heating and so on); lighting environment (sky illumination, mechanical lighting, nature lighting); sound environment (noise analysis, 
Table 1. Characteristics and thermal properties of materials used in the design building.

\begin{tabular}{|c|c|c|}
\hline $\begin{array}{c}\text { Structural } \\
\text { element }\end{array}$ & $\begin{array}{l}\text { Structure and construction method (from outside to } \\
\text { inside) }\end{array}$ & $\begin{array}{l}\mathrm{U} \text {-value }\left(\mathrm{W} / \mathrm{m}^{2} \cdot \mathrm{k}\right) / \text { solar heat } \\
\text { gain coefficient }\end{array}$ \\
\hline Wall 1 & $\begin{array}{c}\text { plastic board }(10 \mathrm{~mm})+\text { rock wool }(50 \mathrm{~mm})+\text { aerated } \\
\text { concrete block }(300 \mathrm{~mm})+\text { cement-lime mortar }(8 \\
\mathrm{mm})\end{array}$ & 0.33 \\
\hline Wall 2 & plain concrete $(300 \mathrm{~mm})$ & 0.96 \\
\hline Roof & XPS board $(70 \mathrm{~mm})+$ Metal deck insulated $(80 \mathrm{~mm})$ & 0.73 \\
\hline Ground & $\begin{array}{l}\text { packed soil }(300 \mathrm{~mm})+\text { gravel pebble }(400 \mathrm{~mm})+\text { air } \\
\text { layer }(500 \mathrm{~mm})+\text { fine aggregate concrete }(100 \mathrm{~mm})+ \\
\text { cement mortar }(20 \mathrm{~mm})\end{array}$ & 0.47 \\
\hline Window & $\begin{array}{c}\text { Low-E glass }(6 \mathrm{~mm})+\text { air layer }(9 \mathrm{~mm})+\text { transparent } \\
\text { glass }(6 \mathrm{~mm})\end{array}$ & $\begin{array}{l}2.4 / \\
0.75\end{array}$ \\
\hline Door & solid wood door $(40 \mathrm{~mm})$ & 2.71 \\
\hline
\end{tabular}

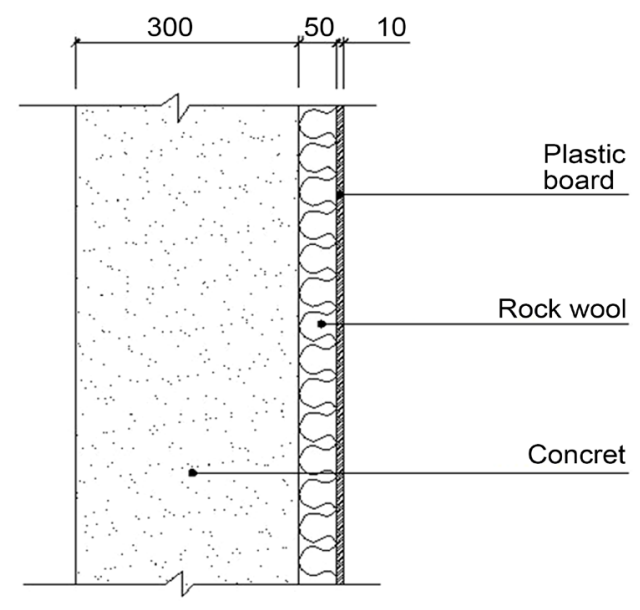

Figure 13. The principle of natural optical light system.

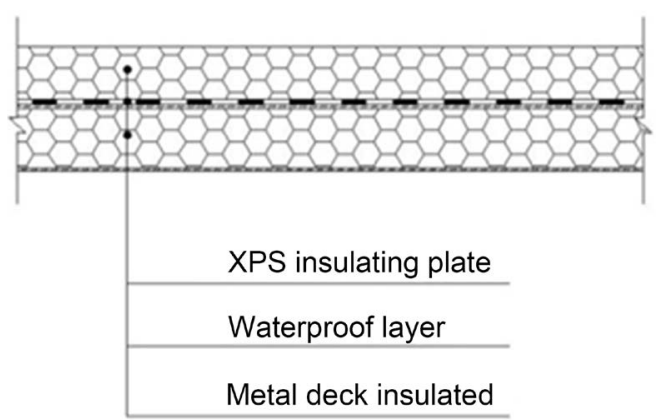

Figure 14. The construction details of the insulation system of the roof.

acoustical design); sunlight environment (sunlight reflector design, shading devices design); economic analysis (cost estimating, resources consumption analysis ); environmental impact and visibility analysis [18].

The methodology used in this paper is to establish the building model by Ecotect software based on the Hangzhou weather data, and the building performance (such as indoor thermal environment, indoor lighting environment and solar radiation level) 
influenced by the variable design conditions are simulated. According to the simulation results, the following are to be discussed and concluded:

1) Modeling studies on the heat gains/loss or solar radiation gains resulted from different building forms to find the optimum shape.

2) Modeling studies on the solar radiation access on the roof surface with different angles to find the best incline.

3) Evaluating the energy consumption difference between the design building and standard building based on monthly cooling/heating loads through modeling simulation.

4) Calculating the external sunshade coefficient, verifying the energy consumption level adding external shading device or not.

5) Verifying the indoor lighting level resulted from metal tube optical system, to find the best diameter size and fenestration on the external wall.

As shown in Figure 4, the building model was set according to the design scheme (Figure 5 and Figure 6). For the purpose of comparison, the model building should be assigned with the same basis information (see Table 2 and Table 3) and envelope properties (see Table 1), so as to analyze and evaluate the simulating results impacted by different design conditions.

\section{Results and Discussion}

\subsection{Building Shape Optimization}

The building Form Coefficient (FC) refers to the ratio of external envelope surface to volume, which influenced the energy consumption greatly. For this reason, FC

Table 2. Characteristics and thermal properties of materials used in the design building.

\begin{tabular}{|c|c|c|}
\hline \multicolumn{2}{|c|}{ Floor area $\left(\mathrm{m}^{2}\right)$} & 58.9 \\
\hline \multicolumn{2}{|c|}{ Net height $(\mathrm{m})$} & 2.7 \\
\hline \multicolumn{2}{|c|}{ Construction height (m) } & 7.2 \\
\hline \multicolumn{2}{|c|}{ Bedroom $1\left(\mathrm{~m}^{2}\right)$} & 9.6 \\
\hline \multicolumn{2}{|c|}{ Bedroom2 $\left(\mathrm{m}^{2}\right)$} & 9.6 \\
\hline \multicolumn{2}{|c|}{ Living room (including dining room) $\left(\mathrm{m}^{2}\right)$} & 22 \\
\hline \multicolumn{2}{|c|}{ Kitchen $\left(\mathrm{m}^{2}\right)$} & 4.9 \\
\hline \multicolumn{2}{|c|}{ Toilet $\left(\mathrm{m}^{2}\right)$} & 4.9 \\
\hline \multirow{4}{*}{ Window size ( height $\times$ width $)$} & South & $1.5 \times 1.2$ \\
\hline & North & $0.6 \times 0.6$ \\
\hline & East & $1.5 \times 1.2$ \\
\hline & West & $1.5 \times 1.2$ \\
\hline \multirow{4}{*}{ Window-wall ratio } & South & 0.14 \\
\hline & North & 0.02 \\
\hline & East & 0.09 \\
\hline & West & 0.09 \\
\hline
\end{tabular}


Table 3. Operational parameters of equipment.

\begin{tabular}{|c|c|c|c|c|c|c|}
\hline \multirow[b]{2}{*}{ Room } & \multirow[b]{2}{*}{ Active system } & \multirow[b]{2}{*}{ Efficiency } & \multicolumn{2}{|c|}{ Comfort band } & \multicolumn{2}{|c|}{ Hours of operation } \\
\hline & & & $\begin{array}{c}\text { Lower } \\
\text { band }\end{array}$ & $\begin{array}{c}\text { Upper } \\
\text { band }\end{array}$ & Week days & $\begin{array}{l}\text { Week } \\
\text { ends }\end{array}$ \\
\hline $\begin{array}{l}\text { Living } \\
\text { room }\end{array}$ & $\begin{array}{c}\text { Full air } \\
\text { conditioning }\end{array}$ & $95 \%$ & $18^{\circ} \mathrm{C}$ & $26^{\circ} \mathrm{C}$ & $\begin{array}{c}22 \text { p.m - } 8 \\
\text { a.m }\end{array}$ & $24 \mathrm{~h}$ \\
\hline Bedroom & $\begin{array}{c}\text { Full air } \\
\text { conditioning }\end{array}$ & $95 \%$ & $18^{\circ} \mathrm{C}$ & $26^{\circ} \mathrm{C}$ & $\begin{array}{c}22 \text { p.m - } 8 \\
\text { a.m }\end{array}$ & $24 \mathrm{~h}$ \\
\hline Kitchen & $\begin{array}{l}\text { Nature ventila- } \\
\text { tion }\end{array}$ & -- & - & -- & -- & - - \\
\hline Toilet & $\begin{array}{l}\text { Nature ventila- } \\
\text { tion }\end{array}$ & - & - & -- & -- & - \\
\hline
\end{tabular}

should be controlled at a relative low value to prevent additional heat loss. In terms of hot summer/cold winter region, FC is not so critical due to the less temperature difference, meanwhile over tight shape will impact on both architects' creation and solar heat gains in winter. Therefore, the building models with different plans (see Figure 15) but the same floor area and height, were simulated and compared for the balance of heat transferring loss and solar radiation gains. According to the results (see Table 4), including the energy consumption, heating loss through envelope and solar energy gains, different building performance were visually reflected by the Figures 16-18.

Figure 16 and Figure 17 indicate that the annual energy consumption is expected to rise as the FC increasing. As shown in Figure 15, the form1 possesses the most simple shape so that the total annual loads is lower than others, while that of form6 is significantly high due to its relatively complex envelope (see Figure 17). For the other form, the annual energy consumption presents little difference because of their similar FC. Further simulating results about the ratio of passive solar radiation gains in heating season (i.e. from 1st Nov. to 30th Apr.) and cooling season (i.e. from 1st Jun. to 30th Sep.) together with that of the heating loss through fabric in heating season are shown in Figure 18. It can be observed that form 1 obtain the lowest solar energy during heating season for the reason of the simplest shape. Although the FC of form 2, 3, 4 and 6 has an increasing tendency, the solar energy gains in winter are not expected so high due to the constant frontage facing to the sun. For the form 5, more compact shape does not contribute in reducing energy consumption because of its bigger deep compare to other models. In addition, it can be observed that the form 3 has relatively low annual loads and high solar heat gains (52\%) in winter, while the solar energy obtained in summer is not so high (39.4\%). Based on the above discussion, the form 3 was selected as the final plan considering the architecture style design, and the external shading can be provided in summer in case of preventing over solar radiation.

\subsection{Roof Angle Optimization}

There are two types: In an earlier study [15], the amount of astronomical solar radiation resulted from the TMY data base of Hangzhou was about $4329 \mathrm{MJ} / \mathrm{m}^{2}$, namely $1202 \mathrm{~kW} \cdot \mathrm{h} / \mathrm{m}^{2} \cdot \mathrm{a}$, where has been identified as the resource-poor area (i.e. between 1160 
$\left.\sim 1400 \mathrm{~kW} \cdot \mathrm{h} / \mathrm{m}^{2} \cdot \mathrm{a}[15]\right)$ of solar energy. According to the evaluation method indicated in the reference [17], there were 273 days in Hangzhou area where has more than 6 hours sunshine duration in each day, taken as the indictor for assessing the value of solar resource utilization. Therefore, it can be observed that the period between May and September in Hangzhou conforms to the requirement. Based on the above discussion, the solar radiation data from TMY of Hangzhou was put into the basic model to

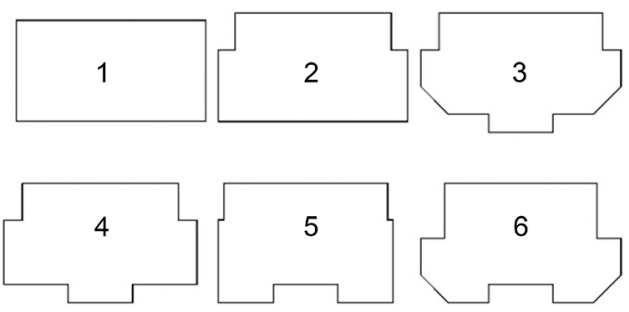

Figure 15. The comparison of different plans.

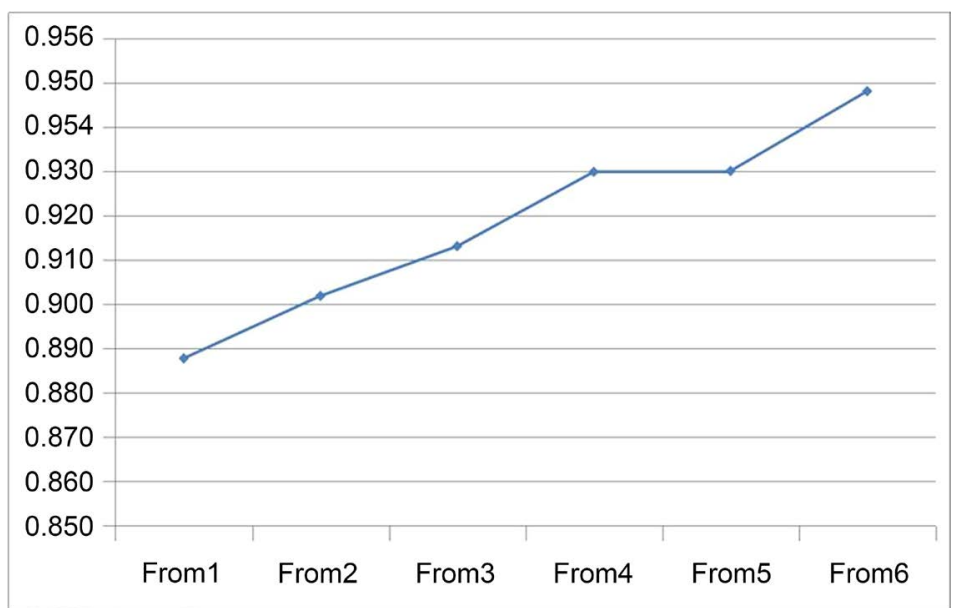

Figure 16. The profile of calculating results of FC.

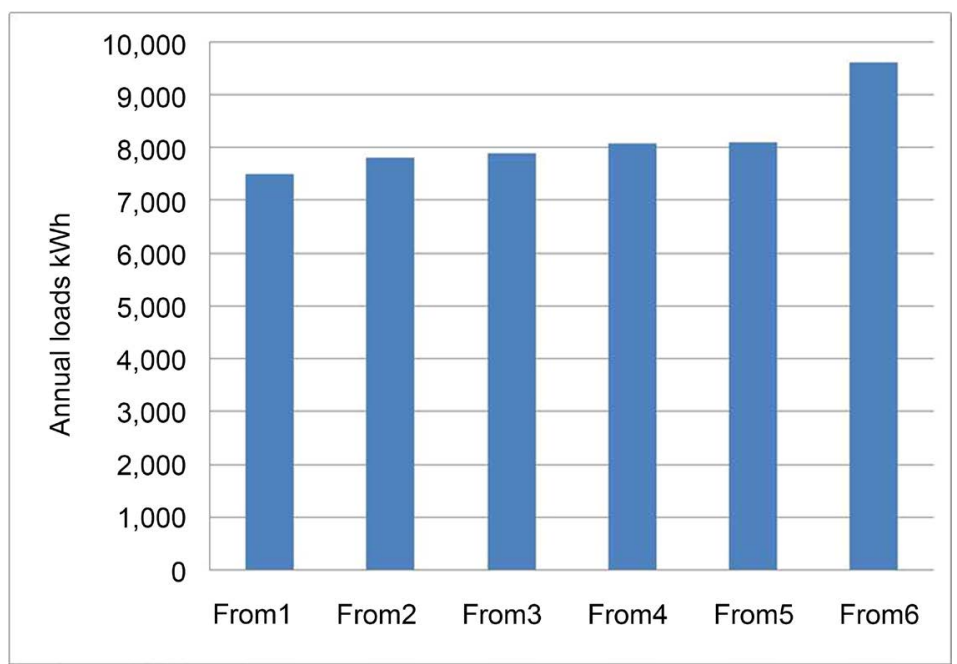

Figure 17. The simulated annual loads of different forms. 


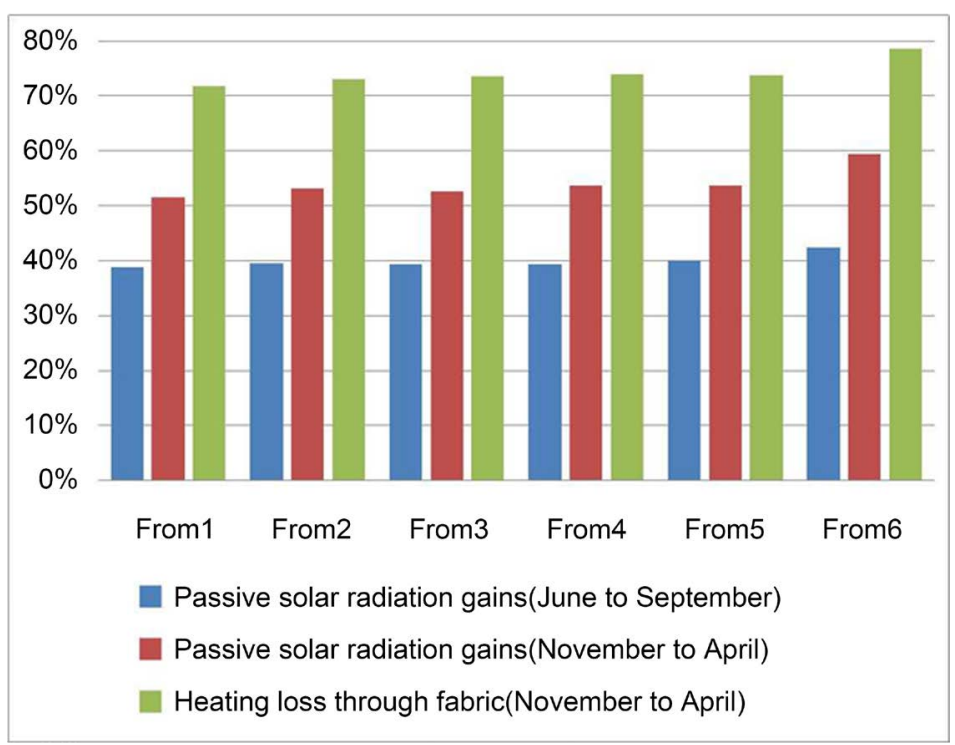

Figure 18. The comparison of the ratio of passive components in different seasons.

Table 4. Summary of simulation and calculating.

\begin{tabular}{|c|c|c|c|c|c|c|c|}
\hline \multirow[b]{2}{*}{ Name } & \multirow[b]{2}{*}{$\mathrm{FC}$} & \multicolumn{2}{|c|}{ Soar gains \% } & \multirow{2}{*}{$\begin{array}{c}\text { Fabric } \\
\text { losses \% } \\
1^{\text {st }} \text { Nov. to } \\
30^{\text {th }} \text { Apr. }\end{array}$} & \multirow{2}{*}{$\begin{array}{c}\text { Max } \\
\text { heating } \\
\text { load } \\
\mathrm{kW} \cdot \mathrm{h}\end{array}$} & \multirow{2}{*}{$\begin{array}{c}\text { Max } \\
\text { cooling } \\
\text { load } \\
\mathrm{kW} \cdot \mathrm{h} \\
\end{array}$} & \multirow{2}{*}{$\begin{array}{c}\text { Annual } \\
\text { loads } \\
\mathrm{kW} \cdot \mathrm{h}\end{array}$} \\
\hline & & $\begin{array}{l}1^{\text {st }} \text { Jun. to } \\
30^{\text {th }} \text { Sep. }\end{array}$ & $\begin{array}{l}1^{\text {st }} \text { Nov. to } \\
30^{\text {th }} \text { Apr. }\end{array}$ & & & & \\
\hline Form 1 & 0.888 & $38.80 \%$ & $51.60 \%$ & $71.80 \%$ & 3469 & 3319 & 7498 \\
\hline Form2 & 0.902 & $39.50 \%$ & $53.10 \%$ & $73 \%$ & 3606 & 3625 & 7803 \\
\hline Form3 & 0.913 & $39.40 \%$ & $52.60 \%$ & $73.60 \%$ & 3613 & 3487 & 7885 \\
\hline Form4 & 0.930 & $39.40 \%$ & $53.60 \%$ & $74 \%$ & 3724 & 3657 & 8072 \\
\hline Form5 & 0.930 & $40.10 \%$ & $53.70 \%$ & $73.70 \%$ & 3716 & 3653 & 8098 \\
\hline Form6 & 0.948 & $42.40 \%$ & $59.40 \%$ & $78.50 \%$ & 4332 & 4079 & 9600 \\
\hline
\end{tabular}

calculate the total solar radiation falling on the variable angles between $0^{\circ} \sim 50^{\circ}$, thereby determining the best degree inclination for the solar panel installation.

As shown in Figure 19, the amount of solar radiation falling on the sloped roof indicates an general increasing tendency as the changing degree of inclination: at the range of $0^{\circ} \sim 5^{\circ}$ angle, the solar heating gains (SHG) is decreasing firstly, and then rising gradually from $5^{\circ}$ to $35^{\circ}$ until reaching the peak value of 578.1. After $35^{\circ}$, SHG appears declining slightly and starts to increase at $50^{\circ}$. This finding presents that SHG (i.e. from 1st May to 30th Sept.) does not keep increasing constantly with the roof inclining, thus the best angle should be $35^{\circ}$. Figure 20 illustrates the SHG profile as the angle changing of roof inclination during the whole year: it can be observed that SHG gradually rise from $0^{\circ} \sim 30^{\circ}$ and then increase suddenly at $32^{\circ}$ where SHG begin to decline until the roof angle become $45^{\circ}$. Thus it can be concluded that the best angle of roof for SHG between Jan. to Dec. should be $32^{\circ}$. Generally considering the architecture style and construction, the roof inclined greatly will lead to the structure stability and un comfortable visual effect, so the angle of roof is determined to be $30^{\circ}$ as the final plan. 


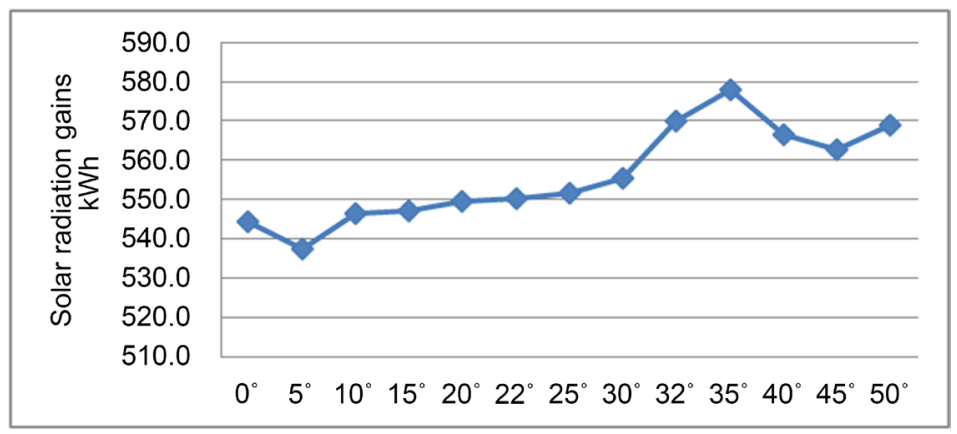

Figure 19. The total solar radiation falling on the variable angles between $0^{\circ} \sim 50^{\circ}$ from May to September.

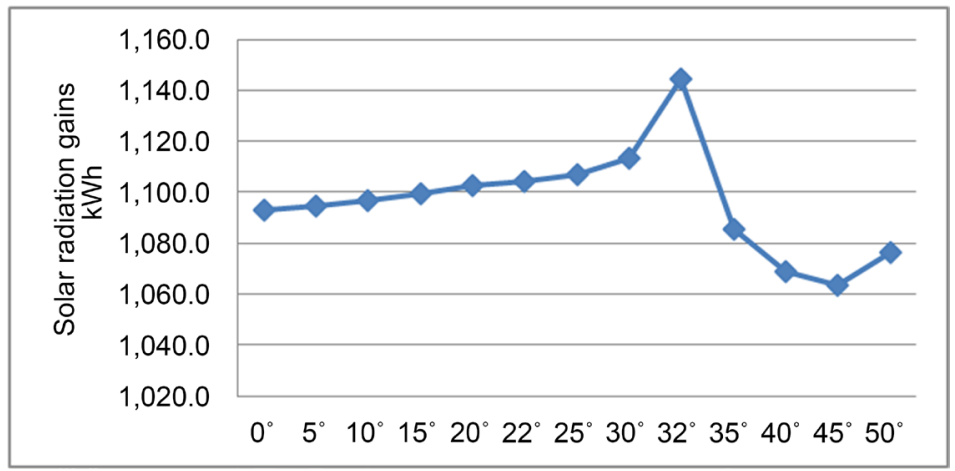

Figure 20. The total solar radiation falling on the variable angles between $0^{\circ} \sim 50^{\circ}$ during the whole year.

\subsection{Effective Factors Analysis of Envelope Insulation System}

The main envelope insulation system including external wall, roof and windows plays the important role on reducing thermal energy and improving indoor comfort. Considering the maximum energy efficiency and the minimum cost, the Ecotect software was used to simulate the variable tendency of annual heating and cooling loads which were the basic indicator of comparison among the wall and roof insulated by different thickness of materials, as well as the window designed various $U$-value (seen in Table 5). It was assumed that the thermal performance of other components remained unchanged while the any one of the components was investigated on influencing the energy loads during the process of simulation. Based upon the precondition, the appropriate $\mathrm{U}$-value of the external wall, roof and window were determined according to the simulating results shown in Figure 21 and Figure 22.

Figure 21(a) shows that the energy consumption presents roughly decreasing tendency as the thicknesses of insulation layer constructed on the wall from $0 \mathrm{~mm}$ to 100 mm respectively: the heating demand of the external wall insulated by rock wool materials declines significantly by $14.2 \%$ (i.e. from $3275.7 \mathrm{~kW} \cdot \mathrm{h}$ to $2810.3 \mathrm{~kW} \cdot \mathrm{h}$ ) compared to the cooling demand from $2278.5 \mathrm{~kW} \cdot \mathrm{h}$ to $2190.5 \mathrm{~kW} \cdot \mathrm{h}$, only by $3.9 \%$. It can be observed that total annual energy consumption mainly influenced by heating demand has a general reduction of $10 \%$ (i.e. from $5554.2 \mathrm{~kW} \cdot \mathrm{h}$ to $5000.9 \mathrm{~kW} \cdot \mathrm{h}$ ), the profile of which 
is relatively obvious from $0 \mathrm{~mm}$ to $50 \mathrm{~mm}$, but begins to level off after that.

From the simulation result (Figure 21(b)) about roof insulated by XPS board, the cooling demand changes obviously with a $24.6 \%$ reduction from $2278.5 \mathrm{~kW} \cdot \mathrm{h}$ to 1717.3 $\mathrm{kW} \cdot \mathrm{h}$, relative to the heating energy consumption dropping down by $15.7 \%$ (i.e. from $3275.7 \mathrm{~kW} \cdot \mathrm{h}$ to $2761.0 \mathrm{~kW} \cdot \mathrm{h}$ ); it can also be seen that the annual total demand decreasing by $19.4 \%$ from $5554.2 \mathrm{~kW} \cdot \mathrm{h}$ to $4478.3 \mathrm{~kW} \cdot \mathrm{h}$ is influenced greatly by the cooling demand change, and the value begins to drop slowly when the insulation lay reaches to the thickness of $70 \mathrm{~mm}$. According to the result, roof insulation is the main factor considered to defend solar radiation in summer, which can be explained by the fact that the most solar radiation access is accepted by horizontal plane in Hangzhou area.

The U-value changing profile of window, illustrated in Figure 22, show that the total demand variation is synchronized with that of heating demand: as the U-value changing from 5.4 to 0.5 , heating demand falls very rapidly (i.e. with $37.1 \%$ reduction from $3275.7 \mathrm{~kW} \cdot \mathrm{h}$ to $2060.1 \mathrm{~kW} \cdot \mathrm{h}$ ) causing an overall decline of annual energy demand by $22 . \%$. While the cooling demands profile has almost no change, only with a $2.5 \%$ reduction from $2278.5 \mathrm{~kW} \cdot \mathrm{h}$ to $2220.5 \mathrm{~kW} \cdot \mathrm{h}$. Based on the figure, it can be concluded that the thermal performance of windows play an important role on the whole energy consumption, especially on reducing heating loss caused by the temperature difference in winter, but has no effect in summer.

According to the above analysis, the optimal thicknesses of insulation layer for wall and roof were decided as $50 \mathrm{~mm}$ and $70 \mathrm{~mm}$ respectively. In term of windows, the best $\mathrm{U}$-value was considered as 2.5 processed by double glazing sandwich-type coated Low-E film, a $9 \mathrm{~mm}$ air gap layer enclosed between two $6 \mathrm{~mm}$ clear glass sheets and insulating aluminum profile.

Table 5. The calculated results of U-value for external wall and roof.

\begin{tabular}{|c|c|c|c|c|c|}
\hline $\begin{array}{l}\text { External wall } \\
\text { structure } \\
\text { (from outside to } \\
\text { inside) }\end{array}$ & $\begin{array}{l}\text { Insulation } \\
\text { layer } \\
\text { thickness } \\
(\mathrm{mm})\end{array}$ & $\begin{array}{l}\text { U value } \\
\left(\mathrm{w} / \mathrm{m}^{2} \cdot \mathrm{k}\right)\end{array}$ & $\begin{array}{l}\text { Roof } \\
\text { structure } \\
\text { (from } \\
\text { outside to } \\
\text { inside) }\end{array}$ & $\begin{array}{l}\text { Insulation } \\
\text { layer } \\
\text { thickness } \\
\text { (mm) }\end{array}$ & $\begin{array}{l}\text { U value } \\
\left(\mathrm{w} / \mathrm{m}^{2} \cdot \mathrm{k}\right)\end{array}$ \\
\hline \multirow{11}{*}{$\begin{array}{c}\text { plastic board } \\
(10 \mathrm{~mm})+\text { rock } \\
\text { wool }(\mathrm{d} \mathrm{mm})+ \\
\text { aerated concrete } \\
\text { block }(300 \mathrm{~mm})+ \\
\text { cement-lime } \\
\text { mortar }(8 \mathrm{~mm})\end{array}$} & 0 & 0.62 & \multirow{11}{*}{$\begin{array}{l}\text { XPS board } \\
(\mathrm{d} \mathrm{mm}) \\
+ \text { metal deck } \\
\text { insulated ( } 80 \\
\mathrm{~mm})\end{array}$} & 0 & 1.23 \\
\hline & 10 & 0.53 & & 10 & 1.12 \\
\hline & 20 & 0.46 & & 20 & 1.03 \\
\hline & 30 & 0.40 & & 30 & 0.95 \\
\hline & 40 & 0.36 & & 40 & 0.88 \\
\hline & 50 & 0.33 & & 50 & 0.82 \\
\hline & 60 & 0.30 & & 60 & 0.77 \\
\hline & 70 & 0.27 & & 70 & 0.73 \\
\hline & 80 & 0.25 & & 80 & 0.69 \\
\hline & 90 & 0.24 & & 90 & 0.65 \\
\hline & 10 & 0.22 & & 10 & 0.62 \\
\hline
\end{tabular}




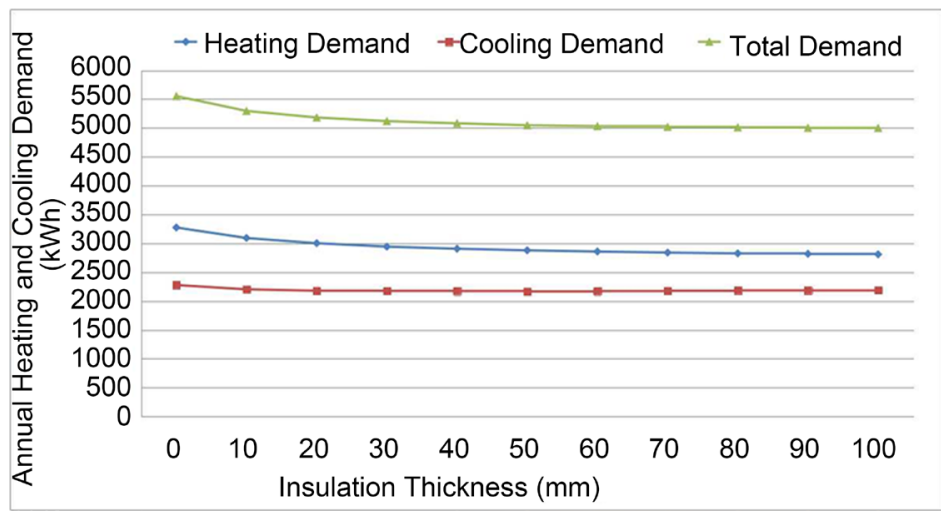

(a)

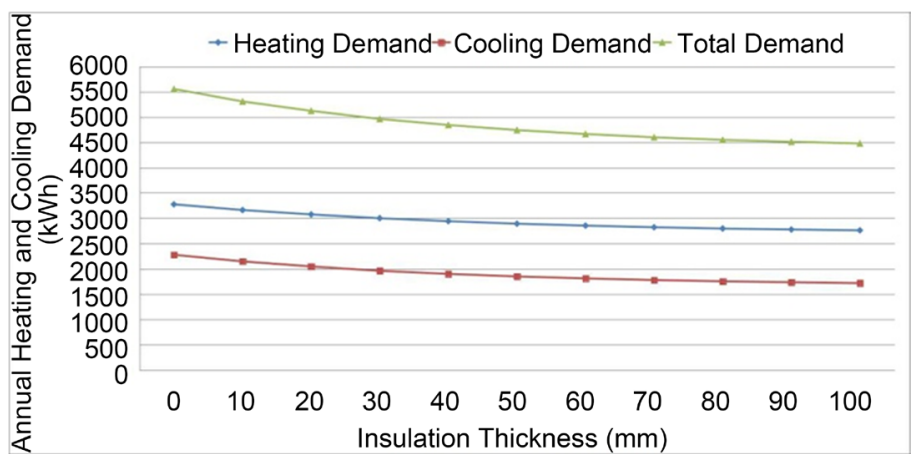

(b)

Figure 21. The profile of the annual energy demand changing with: (a) the different insulation thickness of the wall; (b) the different insulation thickness of the roof.

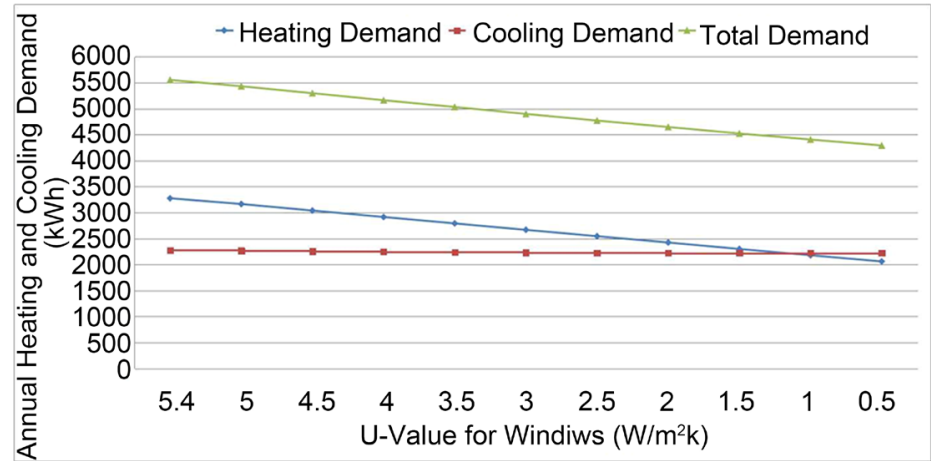

Figure 22. The profile of the annual energy demand changing with different U-value of the window.

Due to the reason that the thermal performance of residential building envelope was definitely regulated in hot-summer/cold-winter region [19], the optimal values selected before and the those listed in the Table 6 were assigned to the model for simulating respectively, thereby comparing the energy demand level with each other. At the same time, the effectiveness of insulation design strategies was evaluated.

Figure 23 indicates that the total energy demand of design building insulated by highly efficient materials is obviously lower than that of standard building, falling down 
Table 6. The comparison of the optimal values and the regulated in standard about the thermal performance of residential building envelope.

\begin{tabular}{|c|c|c|c|c|c|}
\hline & & \multicolumn{2}{|c|}{ Design building } & \multicolumn{2}{|c|}{ Standard building } \\
\hline \multicolumn{2}{|c|}{ Component } & $\begin{array}{c}\text { U-value } \\
\left(\mathrm{W} / \mathrm{m}^{2} \cdot \mathrm{K}\right) / \\
\text { shading } \\
\text { coefficient of } \\
\text { glasses }\left(\mathrm{SC}_{\mathrm{B}}\right)\end{array}$ & $\begin{array}{c}\text { Window-wall } \\
\text { ratio }\end{array}$ & $\begin{array}{c}\text { U-value } \\
\left(\mathrm{W} / \mathrm{m}^{2} \cdot \mathrm{K}\right) / \\
\text { Shading } \\
\text { coefficient of } \\
\text { glasses }\left(\mathrm{SC}_{\mathrm{B}}\right)\end{array}$ & $\begin{array}{c}\text { Window-wall } \\
\text { ratio }\end{array}$ \\
\hline \multicolumn{2}{|c|}{ Roof } & 0.73 & -- & 0.5 & - - \\
\hline \multicolumn{2}{|c|}{ Wall } & 0.33 & -- & 0.80 & - - \\
\hline \multirow{4}{*}{ Window } & South & $2.5 / 0.75$ & 0.14 & $4.0 / 0.94$ & 0.14 \\
\hline & North & $2.5 / 0.75$ & 0.02 & $4.0 / 0.94$ & 0.02 \\
\hline & East & $2.5 / 0.75$ & 0.09 & $4.0 / 0.94$ & 0.09 \\
\hline & West & $2.5 / 0.75$ & 0.09 & $4.0 / 0.94$ & 0.09 \\
\hline
\end{tabular}

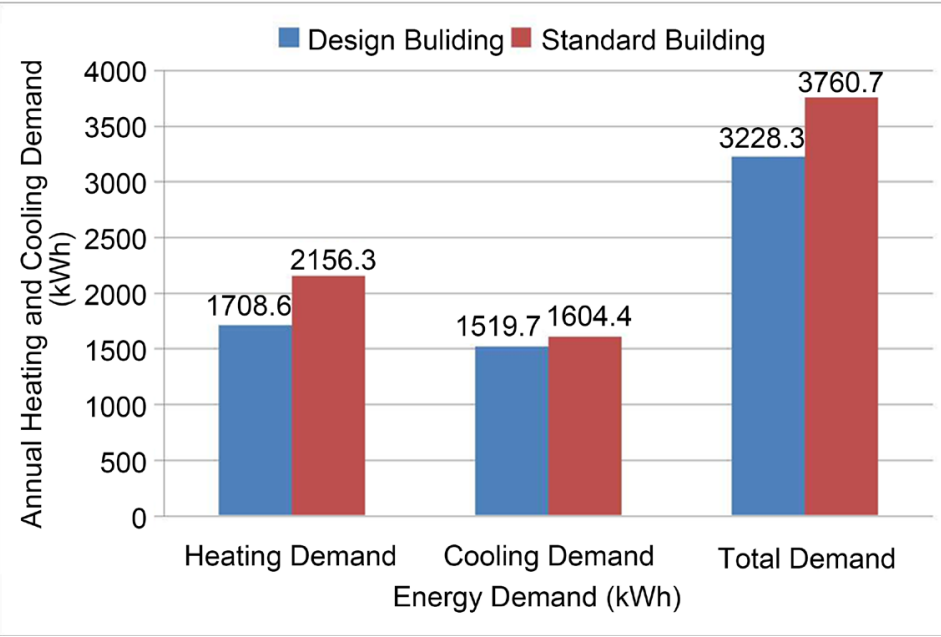

Figure 23. The comparison of annual energy demand of design building and standard building.

by $14.2 \%$ relatively (i.e. from $3760.7 \mathrm{~kW} \cdot \mathrm{h}$ to $3228.3 \mathrm{~kW} \cdot \mathrm{h}$ ). The heating demand profile represents a clear decreasing tendency with $20.7 \%$ from $2156.3 \mathrm{~kW} \cdot \mathrm{h}$ to $1708.6 \mathrm{~kW} \cdot \mathrm{h}$, while the cooling demand has a slight change from $1604.4 \mathrm{~kW} \cdot \mathrm{h}$ to $1519.7 \mathrm{~kW} \cdot \mathrm{h}$, only by $5.3 \%$. The result determined that the objective progress was made in the design building compared to the current regulation.

\subsection{Effective Factors Analysis of Shading Devices for Windows}

Shading design is the important strategy on heat defending in summer of Hangzhou. Different directions should have corresponding shading measures, such as baffle devices for east or west windows, horizontal rectangular devices for south windows and surrounding shade with verticals for southeast or southwest windows.

In this project, the metal baffle shading devices made of adjustable horizontal shutters were designed for the east and west external window, shown in Figure 24. For the south window, the best shading devices should be the horizon sun shield due to the 
reason of Hangzhou location which is on the north of Tropic of Cancer. The size of shading shield can be calculated on the base of the solar altitude and azimuth angles. Firstly, the sun path and control in summer indicate that the horizontal size will be in the large value with solar altitude angle increasing when the sun moves at midday. Otherwise, the wing size of the shield could be decided by the directions of the solar rays, which is get longer as the sun set. In order to fit the facade configuration, the surrounding shade with verticals was selected in the phase of preliminary design, and then the detailed size will be get by using calculation software. For Hangzhou area, the hottest days in a year are usually from May to September when the maximum solar radiation of each day occurs at the range of 10:00 a.m. to 4:00 p.m. [17]. In Ecotect software, the minimum shading size was created automatically according to the input information including date range and time range mentioned above (see Figure 25). By the consideration of shading efficiency and architecture design, the final size of horizontal and vertical shield were both $450 \mathrm{~mm}$, shown in Figure 26.

Normally, integrated shading coefficient of external window (SC) is the important indicator to evaluate the shading effect, relevant to the following factors: shading coefficient of external devices (SD), the shading coefficient of glasses (SCB) and the frame-window area ratio (FK/FC). The formula1 indicates the computing methods about the SC and SD. For the shading configuration designed for east or west window, SC can be calculated by the formula directly; but for the composed device, the value of SD should be the product of that get from horizontal shield and vertical shield respectively. The calculating results are shown in Tables 7-10.

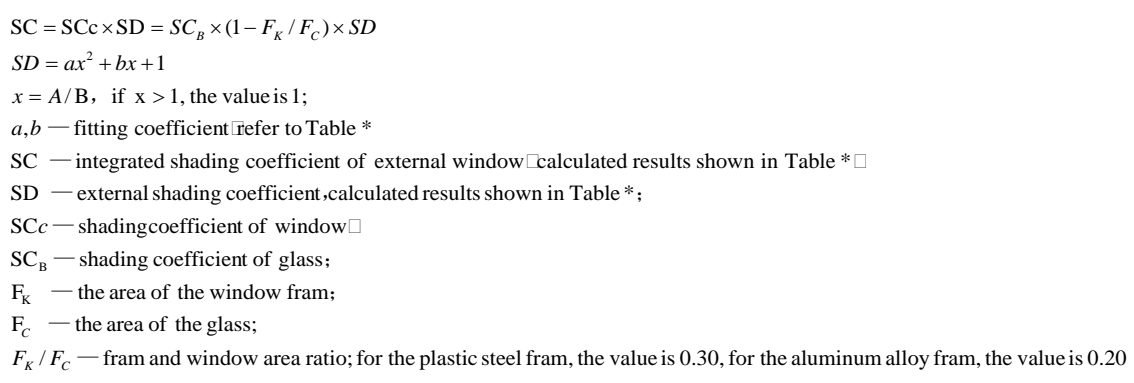

After determining the shading devices style, Ecotect software was used to test the design effect through simulating the monthly cooling demand in TMY. The following design conditions were considered, and the results were shown in Figure 27:

The solar gain coefficient of glasses is 0.75 , and has no any external shading devices;

Only east and west windows were provided with the metal baffle shading devices made of adjustable horizontal shutters, the value of SC seen in Table 10;

Only south windows were provided with integrated shading devices composed of horizontal and vertical shied, the value of SC seen in Table 10;

All the windows were considered with external shading devices, the value of SC seen in Table 10;

Otherwise, the monthly heating demand in TMY was also simulated under these two conditions, and the results were shown in Figure 28:

The solar gain coefficient of glasses is 0.75 , and has no any external shading devices; 
Only south windows were provided with integrated shading devices composed of horizontal and vertical shied, the value of SC seen in Table 10;

Figure 27 indicates that the annual cooling demand has an obvious decrease when only the east and west windows were designed with external shading devices comparing to that being installed outside the south windows only during May to September: especially in May, the cooling demand consumed by the former drops about $13.2 \%$ from $100.2 \mathrm{~kW} \cdot \mathrm{h}$ to $87.1 \mathrm{~kW} \cdot \mathrm{h}$, while that consumed by the later only $2.4 \%$ (i.e. from 100.3 $\mathrm{kW} \cdot \mathrm{h}$ to $98.0 \mathrm{~kW} \cdot \mathrm{h})$. When all the windows use the external sun-shading, the cooling consumption falls down by $14.7 \%$ from $100.3 \mathrm{~kW} \cdot \mathrm{h}$ to $85.6 \mathrm{~kW} \cdot \mathrm{h}$. Even in July, the hottest month in Hangzhou, the cooling demand also has a declination of $8.6 \%$ under east and west shading consideration only, which can be seen that the eastern or western shading design is an important technological strategy in summer of Hangzhou.

In the heating season of Hangzhou, namely from November to next April, the

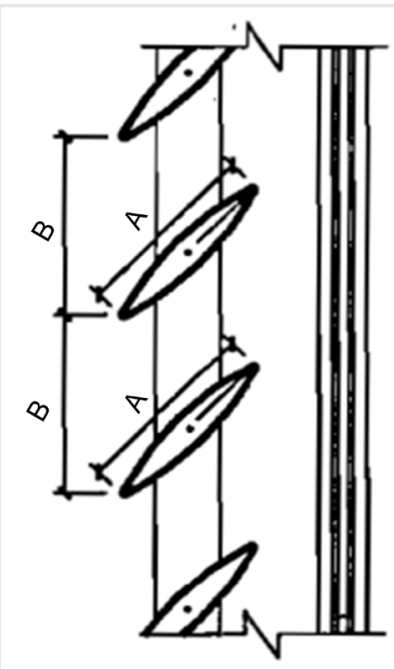

Figure 24. Characteristic value of horizontal shutters.

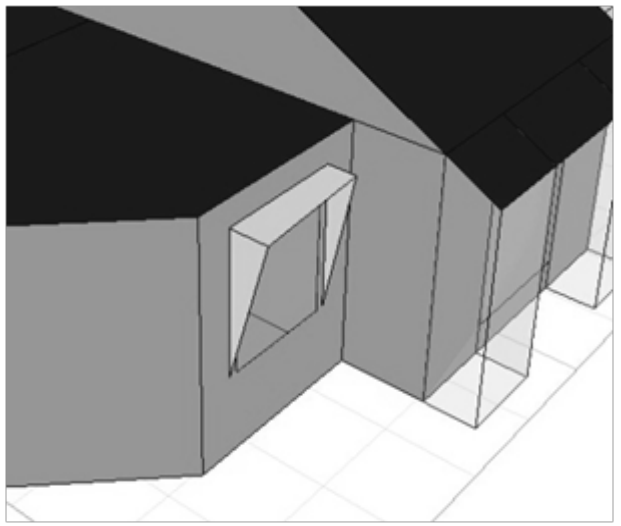

(a)

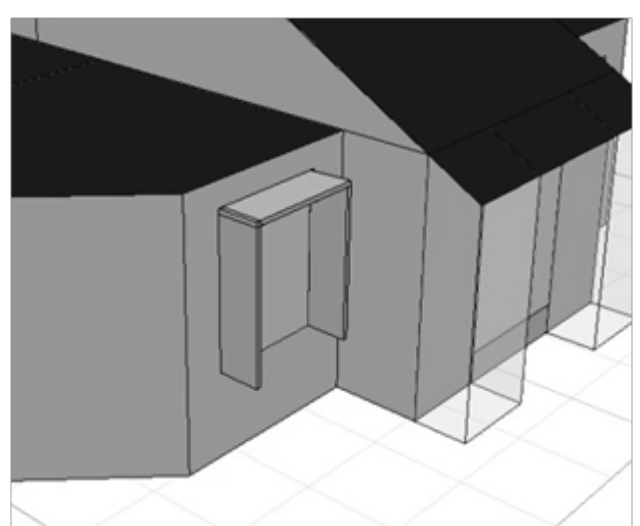

(b)

Figure 25. The configuration of shading device for south window: (a) minimum size generated by software; (b) final designing configuration. 


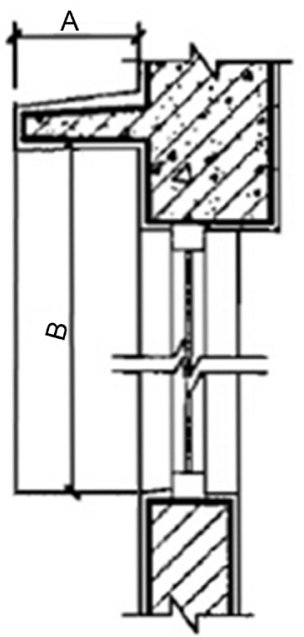

(a)

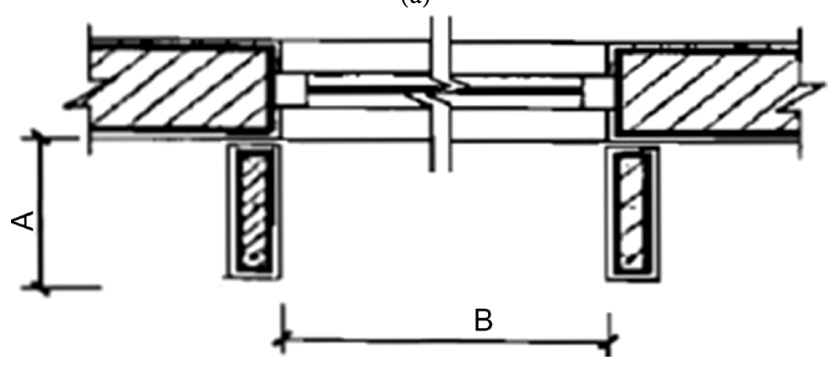

(b)

Figure 26. The characteristic of surrounding shade with verticals: (a) the cross section; (b) the flat section.

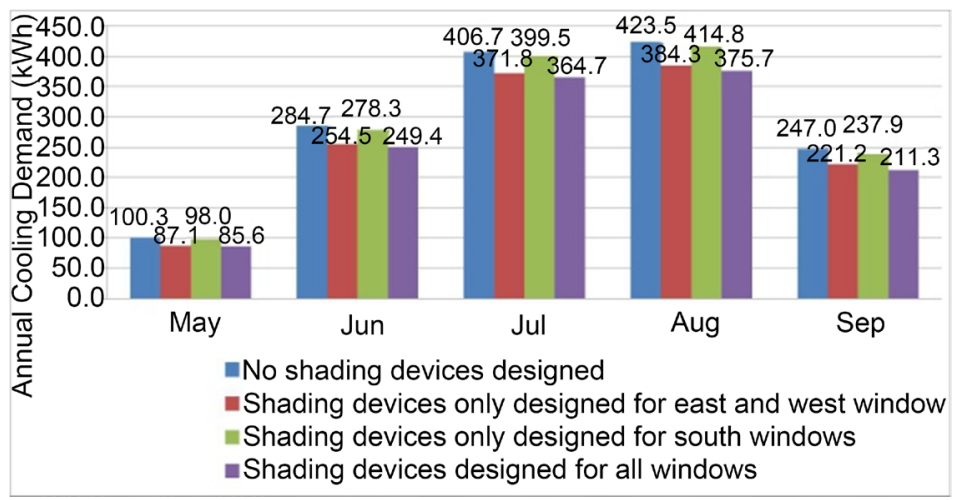

Figure 27. Comparison of annual cooling demand under different solar shading design.

heating demand almost remain unchanged when south windows adopt fixes shading devices, shown in Figure 28: in January, February and December, the value of heating consumption increases slightly as solar energy gains are affected by the external shield, and that in other months rarely changes.

For the further analysis and comparison, the annual heating and cooling demand generated by different shading proposals were presented in Figure 29. When outside shading just used in east and west windows, the annual cooling demand drops by $10.2 \%$ 
Table 7. Fitting coefficient.

\begin{tabular}{|c|c|c|c|c|c|}
\hline Shading type & Fitting co & & East & West & South \\
\hline \multirow{2}{*}{$\begin{array}{l}\text { Adjustable horizontal } \\
\text { shutters }\end{array}$} & \multirow{2}{*}{ Summer } & & 0.56 & 0.57 & - \\
\hline & & & -1.30 & -1.30 & - \\
\hline \multirow{2}{*}{ Fixed horizontal shield } & $\mathrm{a}$ & & - & - & 0.5 \\
\hline & $\mathrm{b}$ & & - & - & -0.8 \\
\hline \multirow{2}{*}{ Fixed vertical shield } & $\mathrm{a}$ & & - & - & 0.33 \\
\hline & b & & - & - & -0.72 \\
\hline
\end{tabular}

Data source: Design Standard Energy Efficiency of Residential Building in Hot Summer and Cold Winter Zone JGJ 134 - 2010

Table 8. Calculated results of SD for east/west window.

\begin{tabular}{ccc}
\hline \multirow{2}{*}{ Season } & \multicolumn{2}{c}{$\mathrm{SD}^{\mathrm{a}}$} \\
\cline { 2 - 3 } & East & West \\
\hline Summer & 0.26 & 0.27 \\
\hline
\end{tabular}

Table 9. Calculated results of SD for south windows.

\begin{tabular}{lccc}
\hline \multicolumn{2}{c}{ Shading type } & & $\mathrm{SD}^{\mathrm{a}}$ \\
\hline \multirow{2}{*}{ Fixed horizontal shield } & $\mathrm{A}$ & 450 & 0.98 \\
& $\mathrm{~B}$ & 1580 & \\
\multirow{2}{*}{ Fixed vertical shield } & $\mathrm{A}$ & 450 & 0.78 \\
& $\mathrm{~B}$ & 1200 & 0.76 \\
\hline
\end{tabular}

a. $\mathrm{SD}=\mathrm{ax} \mathrm{x}^{2}+\mathrm{bx}+1, \mathrm{x}=\mathrm{A} / \mathrm{B} ; \mathrm{b}$. the product of $\mathrm{SD}$ calculated for horizontal shield and for vertical shield respectively.

Table 10. Calculated results of SC for south windows.

\begin{tabular}{cccc}
\hline SC $^{\mathrm{a}}$ & East & West & South \\
\hline Summer & 0.156 & 0.162 & 0.46 \\
\hline
\end{tabular}

a. $\mathrm{SC}=\mathrm{SD} \times \mathrm{SCC}, \mathrm{SCC}=\mathrm{SCB} \times(1-\mathrm{FK} / \mathrm{FC}) ; \mathrm{SCB}=0.75, \mathrm{FK} / \mathrm{FC}=0.2$, then $\mathrm{SCC}=0.6$

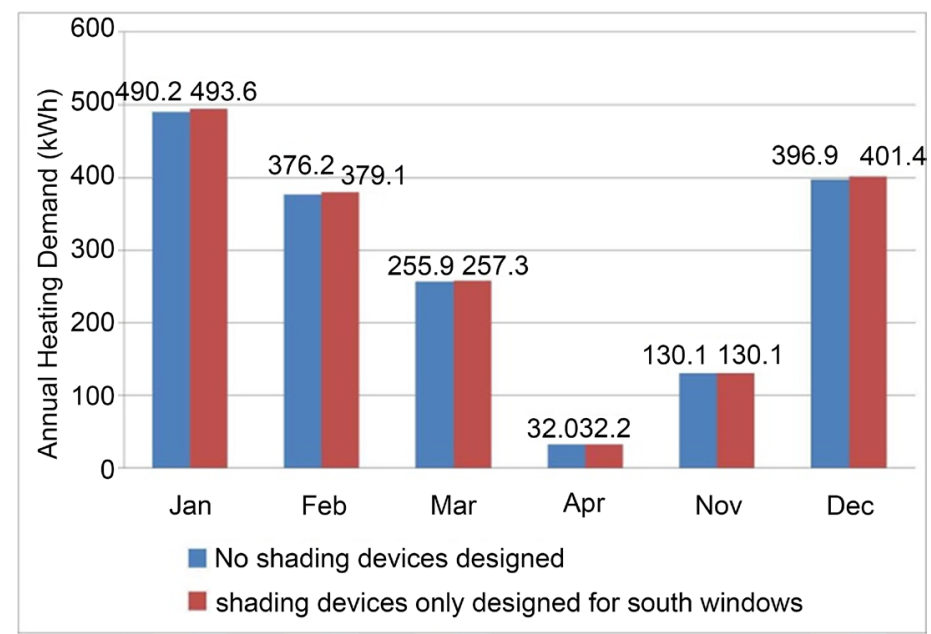

Figure 28. Comparison of annual heating demand under different solar shading design. 
(i.e. from $1517.9 \mathrm{~kW} \cdot \mathrm{h}$ to $1363.3 \mathrm{~kW} \cdot \mathrm{h}$ ), resulting in a $4 \%$ reduction of annual total energy consumption, which is more than prominently it is made by the south windows installed with external shield only, annual cooling consumption decreasing by $2.6 \%$ while the total annual energy consumption falling by less than $1 \%$. The highest energy saving occur when all the windows possess the outside sun-shading and a significant difference between heating and cooling demand was illustrated that the former rises by $2.5 \%$ but the later drops by $12.6 \%$.

Based upon those findings, in order to achieve the maximum energy efficiency through shading design in terms of Hangzhou climate, the external windows should have adjustable sun-shade devices. For the east and west window in this building, the metal baffle made of adjustable horizon shutters should be closed in summer season and open in winter time. On the other hand, the fixed shading shield is not appropriate for south windows. In this project, shading design could be modified as such way: the cantilever size of $450 \mathrm{~mm}$ with adjustable inside vertical shutters, which will either play a shading role effectively in summer or help to solar heating gains in winter.

\subsection{Analysis and Optimization of Nature Lighting}

The lighting quantity of the middle room was simulated and analyzed by using Ecotect software in order to demonstrate the effectiveness of the nature optical lighting system. Simulating conditions for lighting quantity was decided based on the Standard for Daylighting Design of Buildings (GB50033-2013), as shown in Table 11. According to the standard: Hangzhou city belongs to the IV daylight climate in China, the regulated average value of daylight factor should not be less than $1.1 \%$ under the top lighting condition, and the average illuminance of interior daylight should not be less than $165 \mathrm{~lx}$. In terms of the following design conditions, the indoor day-lighting simulating was carried out: when no day-lighting windows on the external wall, the values of daylight factor and illumination were simulated as the changing of the metal optical tube diameter from $500 \mathrm{~mm}$ to $1000 \mathrm{~mm}$ with an increase of $100 \mathrm{~mm}$, as shown in Table 12 .

It can be seen in Table 11, the indoor average day lighting factor only add up to $0.66 \%$ as the tube diameter increasing from $500 \mathrm{~mm}$ to $1000 \mathrm{~mm}$; on the other hand, oversize length will add the difficulty to the structure and influence the visual result. Therefore, single optical tubular system could not meet the requirement of the indoor day-lighting without the additional lighting openings. By overall consideration, the south wall was the only available component to be established with day-lighting opening, which was designed by $1500 \mathrm{~mm}$ wide and $500 \mathrm{~mm}$ high. The new simulated

Table 11. Simulating conditions.

\begin{tabular}{cccccc}
\hline $\begin{array}{c}\text { Transmittance } \\
\text { of tubular } \\
\text { day-lighting } \\
\text { system }\end{array}$ & $\begin{array}{c}\text { Transmittance } \\
\text { of window }\end{array}$ & $\begin{array}{c}\text { Reflectance } \\
\text { of wall }\end{array}$ & $\begin{array}{c}\text { Reflectance } \\
\text { of ceiling }\end{array}$ & $\begin{array}{c}\text { Reflectance } \\
\text { of floor }\end{array}$ & $\begin{array}{c}\text { Outdoor } \\
\text { illumination } \\
\text { design value }\end{array}$ \\
\hline 0.8 & 0.6 & 0.8 & 0.8 & 0.65 & $13500 \mathrm{~lx}$ \\
\hline
\end{tabular}


results obtained from the modified model was shown as Figure 30: by comparison to the and the average illumination was $166 \mathrm{~lx}$. Thus, the design of $1000 \mathrm{~mm}$ diameter optical model only designed tubular optical system, the average day lighting factor was $1.16 \%$ tubular system combined with $100 \mathrm{~mm} \times 500 \mathrm{~mm}$ day-lighting opening would satisfy the standard.

Table 12. The values of daylight factor and illumination.

\begin{tabular}{ccc}
\hline Diameter $(\mathrm{mm})$ & Average day lighting factor (\%) & Average illumination (lx) \\
\hline 500 & 0.21 & 28.15 \\
600 & 0.28 & 37.56 \\
700 & 0.36 & 48.55 \\
800 & 0.45 & 60.38 \\
900 & 0.55 & 73.81 \\
1000 & 0.66 & 88.55 \\
\hline
\end{tabular}

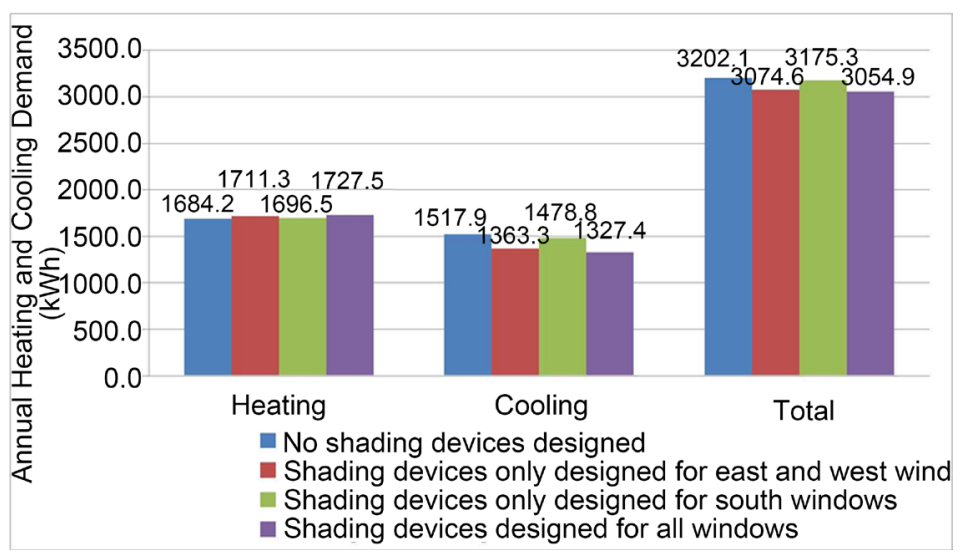

Figure 29. Comparison of annual energy demand under different solar shading design.

(a)

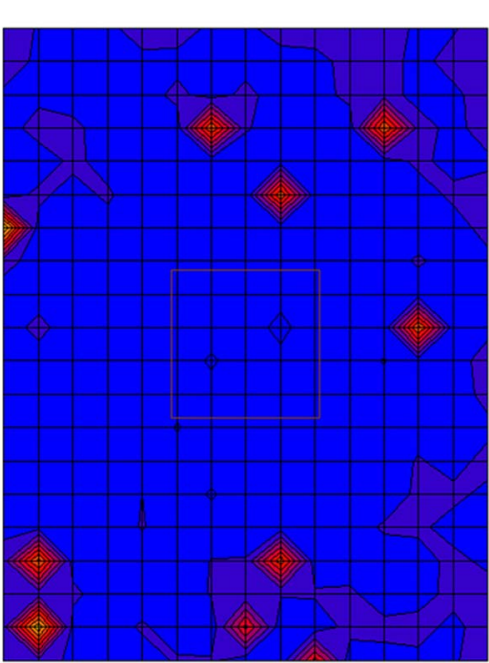

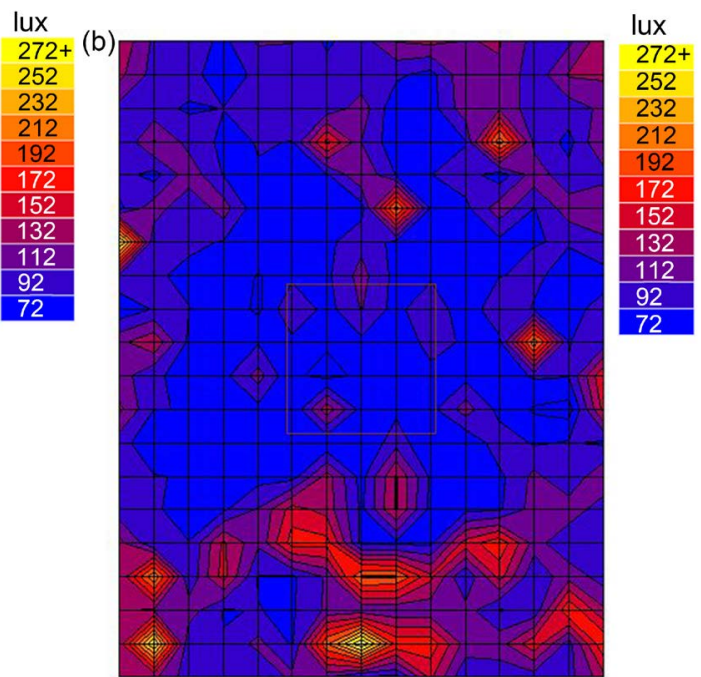

Figure 30. Results of nature lighting simulation (a) Only tubular day-lighting system designed; (b) Extra window designed. 


\section{Conclusions}

As a whole, building construction elements play a significant role in terms of energy consumption and indoor thermal environment, which is restricted by the location, climatic conditions and physical properties of the building. Therefore, the rural residences in the hot summer/cold winter region should be designed economically and appropriately according to the local conditions, moreover be identical with the requirement of ecological sustainable development. In this study, several design strategies provided in a rural residence building for reducing annual energy demand in hot summer/cold winter were introduced and analyzed. By the computer simulating method, some helpful energy-saving design methods were summarized as following:

1) In terms of hot summer/cold winter region, the best optimized energy-saving shape should be considered to minimize the concave-convex change in order to absorb more solar radiation, which has been analyzed and determined by simulation.

2) It can be concluded that the appropriated angle of the roof was $30^{\circ}$, which was beneficial to make the most of the solar energy under the radiation condition of Hangzhou.

3) Through simulating the annual energy demand, the best thick of insulation layer for the wall and roof, as well as the optical U-value for the window were determined. It can be seen that the annual total energy demand resulted from the design building had a $14.2 \%$ reduction compared with the current regulated energy-saving building.

4) The shading devices played an important role in defending solar radiation in summer. Through calculating and simulating, the shading configurations for the east/ west and south window were determined: the horizontal shutters were applied in east/west window, and the fixed horizontal shading device combined with light blocking curtain inside was used for the south window.

5) Through simulation and analysis, the day-lighting design standard could be satisfied by combining optical tubular system with side lighting.

Generally, design working efficiency can be improved greatly if the passive design strategies could be considered in the pre-design process by simulating methods. Through research and analysis, this study is intended to stimulate awareness of energy efficient factors and encourage the integration of these factors into the design and construction of new or renovated rural residential building in the future.

\section{Acknowledgements}

This work was supported by the Department of Education of Zhejiang Province of China (No. FX2014064).

\section{References}

[1] Building Energy Conservation Research Center of Tsinghua University (2012) Annual Development Report on Building Energy Efficiency of China in 2012. Beijing.

[2] Zhu, Y.M. and Liu, J.P. (2007) Exploration of Optimization Measures for Energy Saving Technology of Urban Residential Buildings. Industrial Construction, 37, 1-4. 
[3] Liu, J.L., Chen, W. and Tan, C.Y. (2010) Research Status on Energy Saving Technology of Rural Residential Buildings. Sichuan Building Science, 36, 241-243.

[4] Hangzhou City Bureau of Statistics. Online Source. http://www.hzstats.gov.cn

[5] Wang, M.Y., Ma, J.S. and Wu, Q.C. (2011) Study on the Actual Condition of the Rural Housing and the Application of New Building Materials in Rural Housing, Zhejiang province. Huazhong Architecture, No. 2, 45-47.

[6] Jin, W. Ge, J. and Zhou, X. (2012) Study on the Living Environment and Building Energy Consumption of Rural Areas in Hangzhou. Huazhong Architecture, No. 1, 30-34.

[7] Soussi, M., Balghouthi, M. and Guizani, A. (2013) Energy Performance Analysis of a SolarCooled Building in Tunisia: Passive Strategies Impact and Improvement Techniques. Energy and Buildings, 67, 374-386. http://dx.doi.org/10.1016/j.enbuild.2013.08.033

[8] Peng, M.Y. (2011) The Feasibility Study of the Application of the Passive House in the Northern Area and Hot-Summer and Cold-Winter Region of China. Construction Science and Technology, No. 5, 48-54.

[9] Zhan, L. (2010) Theory and Practice on Energy-Saving Technology of Residential Building in Hot Summer and Cold Winter of China. Sichuan Building Science, 36, 264-267.

[10] Wang, L., Tian, W.L. and Wang, L.J. (2011) Studies on the Design of Passive Solar Ecological Residence. Industrial Construction, 41, 53-70.

[11] Yu, K.J. and Song, B.M. (2010) Low-Carbon Building-Transformation Design of Beijing Heshi Department. Architecture Journal, No. 8, 33-36.

[12] Li, J.N. (2007) Design and Practice on a Low-Energy Ecological Residence in Hot Summer and Cold Winter Region. Architecture Journal, No. 11, 16-18.

[13] Wang, J. (2014) Design and Practice on the Brook Passive House in Changxing. Construction Science and Technology, No. 19, 31-36.

[14] Ren, J. and Wang, W.J. (2015) Using Ecotect Software to Simulation and Analysis on Indoor Thermal Environment of Herders' Residential Houses in Turpan Area of Xinjiang. Sichuan Building Science, 41, 295-299.

[15] Sun, S., Liang, J. and Sun, C. (2015) The Research of Digital Simulation Technique Applied in the Simulation of Energy-Saving in Library Exterior-Protected Construction. Digital Tectonic Culture, 268-273.

[16] Hangzhou Meteorology. Online Source. http://www.hzqx.gov.cn/

[17] Yan, Y., Ge, J., Zhu, Y.H., Zhu, T.T. and Shen, T.T. (2015) Methods on Solar Energy Utilization of Hangzhou Countryside Dwellings During the Urbanization Process. Urban Problems, No. 3, 38-43.

[18] Shou, L.L. (2013) Comparative Research on Building Energy Consumption Analysis Based on BIM with Traditional Building Energy Consumption Analysis of China. Chongqing University, Chongqing.

[19] Ministry of Construction of the People's Republic of China (2010) Design Standard for Energy Efficiency of Residential Buildings in Hot Summer and Cold Winter Zone (JGJ 234-2010). Ministry of Construction of the People's Republic of China, Beijing. 
Submit or recommend next manuscript to SCIRP and we will provide best service for you:

Accepting pre-submission inquiries through Email, Facebook, LinkedIn, Twitter, etc. A wide selection of journals (inclusive of 9 subjects, more than 200 journals)

Providing 24-hour high-quality service

User-friendly online submission system

Fair and swift peer-review system

Efficient typesetting and proofreading procedure

Display of the result of downloads and visits, as well as the number of cited articles

Maximum dissemination of your research work

Submit your manuscript at: http://papersubmission.scirp.org/ 